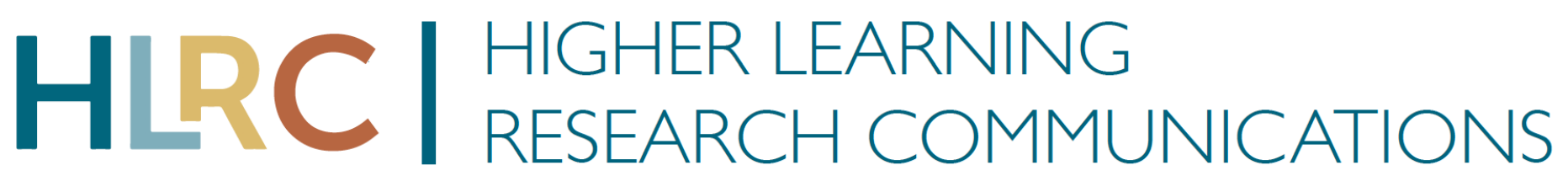

Higher Learning Research Communications

2020, Volume 10, Issue 2, Pages 20-37. DOI: 10.18870/hlrc.v10i2.1188

\title{
Creating, Implementing, and Redefining a Conceptual Framework for Mentoring Pathways for Education Doctorate Students
}

Rebecca D. Brown, EdD

Ball State University, Muncie, Indiana, United States

(iD https://orcid.org/0000-0001-5934-3591

Rachel Louise Geesa, EdD

Ball State University, Muncie, Indiana, United States

(iD https://orcid.org/o0oo-0002-8126-8118

Kat R. McConnel, MA

Marquette University, Milwaukee, Wisconsin, United States

(iD https://orcid.org/0000-0001-6594-3312

Contact: rdbrown2@bsu.edu

\section{Abstract}

Supporting the proficiencies scholar-practitioners need to be successful in Doctor of Education (EdD) programs typically differ from the needs of traditional doctoral students in other types of programs; however, EdD students may benefit from participating in a mentoring program during the progression of their academic career. Several theoretical and conceptual frameworks that influence mentoring programs exist at the doctoral level despite the lack of research conducted that is specific to EdD degrees. In this article, we review several frameworks that influenced the creation and redesign of the Mentoring Pathways Program, developed explicitly to address the needs of scholar-practitioners attending a midwestern university. Through this process, we developed a Mentoring Pathways Program Model, by exploring the domains of sustainability, networking, and expected outcomes, with each domain enhanced through the foundational disciplines of readiness, self-efficacy, and progress. The development and implementation of the MPP model guides the mentoring approach for our EdD students while allowing for the flexibility to accommodate changing needs and requests. In this article, we present a reflective and responsive practice towards EdD mentor and mentee relationships, which are assessed yearly through surveys, interviews, and focus groups.

Keywords: mentoring; conceptual framework; higher education; doctoral students; scholar-practitioner; EdD Submitted: June 18, 2020 | Accepted: August 3, 2020 | Published: September 14, 2020

\section{Recommended Citation}

Brown, R. D., Geesa, R. L., \& McConnel, K. R. (2020). Creating, implementing, and redefining a conceptual framework for mentoring pathways for education doctorate students. Higher Learning Research Communications, 10(2) 2037. DOI: $\underline{10.18870 / \text { hlrc.v10i2.1188 }}$ 


\section{Mentoring Pathways for Education Doctorate Students}

Mentoring programs at the university level often represent a myriad of designs and implementation processes. The structure of doctoral mentoring programs for students pursuing an education doctorate (EdD) varies based on factors related to the degree program, professional aspirations, and personal needs (Geesa et al., 2020; Geesa, et al., 2018; Lowery et al., 2018, 2019; McConnell et al., 2019, 2020). Mentoring programs may be (a) short term or long term; (b) highly structured, semi-structured, or informal; and (c) developmental, reciprocal, peer oriented, reverse, or group oriented (Crisp \& Cruz, 2005; University of Melbourne, 2012). Each approach is a targeted method meant to fulfill an explicit need for mentors, mentees, or a specific program. The vagueness surrounding an operational definition of mentoring in professional literature, however, may complicate how programs use the term "mentoring" or how mentoring programs are executed (Burlew, 1991; Crisp \& Cruz; Jacobi, 1991). Additionally, institutional design processes and expectations create unique approaches to developing and implementing mentoring programs (Baker, 2015), and EdD programs are often designed to meet the unique needs of scholar-practitioners, distinguishing them from the focus of more traditional Doctor of Philosophy (PhD) programs.

As is often the case in the beginning stages of developing an idea and design, mentoring programs are typically designed with the intention to fulfill a perceived or assumed need of the collegiate department and its students. This purpose is often determined through feedback provided by alumni, current students, and associated faculty of a particular program but may also be gained through university-wide initiatives and interdepartmental discussions (Geesa et al., 2020; McConnell et al., 2020). Within the development and implementation process of a mentoring program, several design elements should be considered, including, but not limited to, objectives, mentor and mentee roles, time, selection processes, training needs, and identification of the type of training required (Dawson, 2014). According to Burlew (1991), two questions must be considered within the context of a mentoring program to increase the chance of success: (1) "What exactly is a mentor?" and (2) "What is the conceptual framework(s) guiding the design of these programs?" (p. 213). In this paper, we address both questions in the context of developing a mentoring conceptual framework model and redesigning a doctoral-level mentoring program for EdD students in the field of educational leadership that we refer to as a "Mentoring Pathways Program."

\section{Mentoring Defined}

A single definition of mentoring does not exist, and scholars provide a variety of ways to define mentoring and the roles of mentors and mentees. Eby and colleagues (2010) state "mentoring is everywhere, everyone thinks they know what mentoring is, and there is an intuitive belief that mentoring works" (p. 7). In 1991, Jacobi identified 15 definitions of mentoring, six of which are specific to the field of higher education. These definitions refer to a hierarchical approach (e.g., expert versus novice) that offer support and guidance. Despite the common theme, the lack of an operational definition in mentoring not only devalues the "concept of application in 'hard' research" (Jacobi, 1991, p. 508), but also confuses how specific frameworks look in practice. For example, several theoretical and conceptual frameworks in mentoring use broad terminology when categorizing the process into subsets, as shown in Table 1 . This list is not comprehensive of every available framework and does not address overlapping ideas; however, it does illustrate how widely mentoring is influenced and defined.

For the purpose of our program, we define mentoring as a mutually beneficial relationship between scholarpractitioners in the field of education that does not adhere to the typical tiered approach, but rather supports readiness, self-efficacy, and progress by providing sustained support and networking opportunities to achieve the participants' desired outcomes. 
Table 1: Domains for Theoretical and Conceptual Frameworks in Mentoring

\begin{tabular}{|c|c|c|c|c|}
\hline Authors & Framework & $\begin{array}{l}\text { Type of } \\
\text { Framework }\end{array}$ & Domains & Influences \\
\hline Lent et al. (1994) & $\begin{array}{l}\text { Social Cognitive } \\
\text { Career Theory }\end{array}$ & Theoretical & $\begin{array}{l}\text { - Self-efficacy } \\
\text { - Instrumental } \\
\text { - Expressive } \\
\text { - Sponsorship }\end{array}$ & $\begin{array}{l}\text { Self-Efficacy Theory } \\
\text { (Bandura, 1977) } \\
\text { Social Cognitive } \\
\text { Theory (Bandura, } \\
\text { 1986) }\end{array}$ \\
\hline $\begin{array}{l}\text { Simmie \& Moles } \\
\text { (2011) }\end{array}$ & $\begin{array}{l}\text { Productive } \\
\text { Mentoring }\end{array}$ & Theoretical & $\begin{array}{l}\text { - Critical Inquiry } \\
\text { - Reflective } \\
\text { Dialogue } \\
\text { - Sustainability }\end{array}$ & $\begin{array}{l}\text { Apprenticeship } \\
\text { Model, Competency } \\
\text { Model, Reflective } \\
\text { Practitioner Model } \\
\text { (Maynard \& } \\
\text { Furlong, 1995) } \\
\text { Humanistic Model } \\
\text { (Wang \& Odell, } \\
\text { 2007) } \\
\text { Teacher } \\
\text { Professional } \\
\text { Cultures } \\
\text { (Hargreaves \& } \\
\text { Fullan, 2000) }\end{array}$ \\
\hline Kram (1983) & $\begin{array}{l}\text { Mentoring Phases } \\
\text { Model }\end{array}$ & Conceptual & $\begin{array}{l}\text { - Career } \\
\text { - Psychosocial }\end{array}$ & $\begin{array}{l}\text { Adult Development } \\
\text { Theory (Levinson, } \\
\text { 1978) }\end{array}$ \\
\hline $\begin{array}{l}\text { Yob \& Crawford } \\
(2012)\end{array}$ & Mentoring Model & Conceptual & $\begin{array}{l}\text { - Academic } \\
\text { - Psychosocial }\end{array}$ & $\begin{array}{l}\text { Mentoring Model } \\
\text { (Kram, 1983) }\end{array}$ \\
\hline
\end{tabular}

\section{Theoretical Foundations in Mentoring Frameworks}

Several developmental and learning theories inform mentoring frameworks (see Table 1). Selecting theories that best align with institutional, collegiate, and departmental missions and expected outcomes can be a tedious and chaotic task when considering the overlap that often occurs among the research-based ideologies (Burlew, 1991; Crisp \& Cruz, 2008; Dawson, 2014; Dominguez \& Hager, 2013; Gaskill, 1993; Jacobi, 1991). This section includes theoretical foundations that have influenced the development of our own conceptual framework model for mentoring and guided the creation of the Mentoring Pathways Program, discussed later in this paper.

\section{Self-Efficacy and Social Cognitive Theories}

Bandura's (1977) self-efficacy theory (SET) offered a new perspective on human behavior regarding outcomes by suggesting that an individual's success is rooted in one's belief that one possesses the ability to achieve a specific outcome. While a person's perceived self-efficacy can impact one's own success, witnessing others perform successfully (i.e., without any adverse consequences) can increase or decrease an individual's personal belief in achieving a similar outcome (Bandura, 1986; Varghese \& Finkelstein, 2020). The basis of 
this theory appears simple-belief leads to success-but it is important to note that an individual's "selfefficacy belief system is a differentiated set of self-beliefs linked to distinct realms of functioning, not a onesize-fits-all trait” (Bandura, 2019, p. 13).

The introduction of social cognitive theory (SCT) connected self-efficacy to cognition in offering the explanation that individuals "draw on their knowledge and cognitive and behavioral skills to produce desired results" (Bandura, 1986, p. 1181). Thus, one must consider the environmental impact on an individual's social cognitive conditions, which can positively or negatively influence a person's self-efficacy belief levels (1986, 1997). Through requisite contexts, individuals interact with physical and sociostructural environments that are beyond their control, but individuals may also elect to interact with specific settings that provide personal or career opportunities based on the potential for achievement. How individuals experience satisfying levels of productivity and success in the selected surroundings impacts self-efficacy, which may lead them to create environments that promote continued success (Bandura, 1997; Varghese \& Finkelstein, 2020). From this expanded perspective, one could argue that variations among doctoral students' belief systems require a flexible approach to instruction and mentoring that promotes high self-regulatory skills to increase motivation and achievement (Burney, 2008).

Research of SET and SCT in various settings indicates that an individual's self-efficacy levels can be positively influenced by mentors with whom they identify (Bandura, 1997; Martin \& Dowson, 2009; Meyer \& Bouchey, 2010). Matching mentors and mentees based on common interests and goals (both academic and career) increases "the scope for academic motivation, engagement, and achievement" (Martin \& Dowson, 2009, p. 328). Additionally, a mentor's perceived self-efficacy level also impacts how both the mentor and mentee view the success of their shared relationship (Larose, 2013; Martin \& Dowson, 2009; Varghese \& Finkelstein, 2020). Mentors who assess themselves as confident and successful at modeling and communicating the required components of the mentoring position often have protégés who view themselves in the same manner.

\section{Social Cognitive Career Theory}

Social cognitive career theory (SCCT), developed by Lent et al. (1994), combines the measures of "cognitive, self-regulatory, and motivational processes" with career behaviors, as well as placing self-efficacy at the center of a career development model (p. 259). Within this model, SCCT incorporates three specific entities of SCT (Bandura, 1986): self-efficacy, outcome expectations, and personal goals (Lent et al., 1994). In 2013, the model was extended to include adaptability as a means through which individuals maneuver both ordinary tasks (e.g., career choice) with unpredictable life events (Lent \& Brown, 2013). This combined model addresses the evolution of how one focuses their own behaviors (i.e., career and educational) in different settings. As applied to doctoral-level mentoring, this foundational quartet provides an avenue to examine how candidates' beliefs are influenced through a mentoring program regarding their career choice, along with the level of impact this influence has over their progression through the doctoral program (Curtin et al., 2016).

The application of SCCT has spanned several career fields and applications, including higher education and mentoring at the doctoral level (Bandura, 2019; Carpenter et al., 2015; Connolly et al., 2018; Curtin et al., 2016). A study conducted by Connolly and colleagues (2018) demonstrated how SCCT can be applied to the university platform through a strategy known as teaching development (TD). This approach consists of a variety of programs that target increasing knowledge, skills, and values in late-stage doctoral students, as well as early-career scholars. With opportunities ranging from low to high engagement, participants are able to select TD based on their interests and self-efficacy beliefs, which in turn impacts their desired outcome. While the focus of this particular study was on collegiate-level teachers, TD programs could be designed for the purpose of mentoring EdD students throughout their program, as many aspire to move into higher-level positions. 


\section{Adult Development Theory}

One of the most cited theories for mentoring frameworks is Levinson's (1978) adult development theory (ADT), which posits that an individual experiences life through a series of both stable and transitional periods. This cyclical progression produces changes in the structure of one's life and continues well into adulthood. In his publication The Seasons of a Man's Life (1978), Levinson speaks specifically to the mentor relationship through several lenses, defining it "not in terms of formal roles but in terms of the character of the relationship and the functions it serves" (p. 98) while also referring to mentors as "transitional figures" that "represent a mixture of parent and peer" (p. 99). It is within this context of developmental relationships, along with the identification of psychosocial and career functions, that Kram $(1983,1985)$ developed a model of mentoring phases, which will be discussed in greater depth in the next section.

In addition to Levinson's (1978) theory, Vygotsky's (1978) sociocultural theory relates to mentoring as well. While Vygotsky's idea of the zone of proximal development (ZPD) is traditionally applied to children, the scaffolded approach can also be directed at adult participation in doctoral programs. The ZPD is described as "the distance between the actual development level as determined by independent problem solving and the level of potential development as determined through problem solving... in collaboration with more capable peers" (Vygotsky, 1978, p. 86). We argue that adult learners in any educational program would benefit from mentors who have experienced similar paths to those they are mentoring. The ZPD, while shifted in developmental levels, still exists where learning occurs, aligning with Levinson's (1978) life phases and, likewise, the work of Kram $(1983,1985)$.

\section{Productive Mentoring}

More modern theoretical frameworks continue the approach of academic and emotional support while also addressing the need for professional agency. In 2011, Simmie and Moles published the productive mentoring framework, which engages both a learner-centered and democratic approach in which theory informs practice. Based in critical inquiry and reflective dialogue, sustainability is promoted through the framework's recognition that mentees' needs are constantly changing as society's needs are changing. Unlike the other theoretical frameworks mentioned in this article, productive mentoring rejects the idea of "novice-expert relationships with limited facility for critical co-inquiry," instead promoting an equal playing field in which all participants are posited as competent and valued, regardless of experience in the field (p. 466). Within a mentoring program, then, both the mentors and the mentees must be provided with space to grow personally, academically, and professionally. This requires a "philosophy of care" in which participants critically think about and contribute to the learning of all involved (p. 471). This framework underlines our efforts in designing and redesigning the Mentoring Pathways Program not only to better serve the needs of the doctoral education students but also to create a more collaborative and shared space for discussion, reflection, and goal setting. 
Brown et al., 2020

Table 2: Summary of Theoretical Foundations That Inform Mentoring Frameworks

\begin{tabular}{|c|c|c|}
\hline Theory & Key Concepts & $\begin{array}{l}\text { Alignment to Mentoring } \\
\text { Pathways Program }\end{array}$ \\
\hline $\begin{array}{l}\text { Self-Efficacy Theory (Bandura, } \\
\text { 1977) }\end{array}$ & $\begin{array}{l}\text { Individual belief of ability to } \\
\text { achieve specific outcomes. }\end{array}$ & $\begin{array}{l}\text { EdD students voluntarily } \\
\text { participate in MPP. }\end{array}$ \\
\hline $\begin{array}{l}\text { Social Cognitive Theory } \\
\text { (Bandura, 1986) }\end{array}$ & $\begin{array}{l}\text { Environment influences } \\
\text { individual belief of ability to } \\
\text { achieve specific outcomes. }\end{array}$ & $\begin{array}{l}\text { EdD students network and learn } \\
\text { from others in the field through } \\
\text { participation in MPP. }\end{array}$ \\
\hline $\begin{array}{l}\text { Social Cognitive Career Theory } \\
\text { (Lent et al., 1994) }\end{array}$ & $\begin{array}{l}\text { Individual belief and } \\
\text { environmental factors influence } \\
\text { one's ability to achieve specific } \\
\text { career outcomes. }\end{array}$ & $\begin{array}{l}\text { EdD students align themselves } \\
\text { with MPP mentors who share } \\
\text { common interests, experiences, } \\
\text { and career pathways. }\end{array}$ \\
\hline $\begin{array}{l}\text { Adult Development Theory } \\
\text { (Levinson, 1978) }\end{array}$ & $\begin{array}{l}\text { Relationships are impacted by } \\
\text { transitional figures in one's life. }\end{array}$ & $\begin{array}{l}\text { EdD students experience } \\
\text { relationship opportunities } \\
\text { through MPP. }\end{array}$ \\
\hline $\begin{array}{l}\text { Productive Mentoring Theory } \\
\text { (Simmie \& Moles, 2011) }\end{array}$ & $\begin{array}{l}\text { Theory informs practice through } \\
\text { a learner-centered and } \\
\text { democratic approach. }\end{array}$ & $\begin{array}{l}\text { EdD students' interests and } \\
\text { topic suggestions are the basis of } \\
\text { MPP sessions, not hierarchical } \\
\text { in approach. }\end{array}$ \\
\hline
\end{tabular}

Note. MPP = Mentoring Pathways Program.

\section{Conceptual Frameworks in Mentoring}

Over the past several decades, researchers have developed and published a few conceptual framework models for mentoring. Similar to the theoretical and learning frameworks previously mentioned, the multitude of mentoring models can be challenging and time-consuming to sift through to identify those that best align with a program's intent, despite clear alignment with specific theory. In regards to Burlew's (1991) second question, the models mentioned in this section have influenced the design and redesign of the Mentoring Pathways Program.

\section{Mentoring Phases Model}

Mentoring literature continues to support the need for embedded mentoring structures in various settings, while citing Kram's work $(1983,1985)$ as a foundational source specific to the areas of career and psychosocial mentoring but also in regards to how the mentoring relationship changes over time (Carpenter et al., 2015; Chun et al., 2012; Curtin et al., 2016; Dominguez \& Hager, 2013; Paglis et al., 2006; Tonidandel et al., 2007). Based primarily on the theoretical work of Levinson (1978), Kram developed a mentoring model that "clarifies the phases of a mentor relationship by systematically delineating the psychological and organizational factors that cause movement from one phase to the next" (1983, p. 610). Although Kram's model focuses on mentoring in business, the application to mentoring doctoral students in higher education mimics a similar relationship (i.e., advisor-student) (Paglis et al., 2006). The four phases of Kram's model (1983)-initiation, cultivation, separation, and redefinition-represent a natural relationship progression in an academic program. As students move from the beginning of the mentor relationship to a time in which the relationship eventually evolves into a new form or simply ends, several changes have occurred in both the individuals and the relationship itself. These changes include both career-oriented and psychosocial aspects, in which 
individuals experience career advancement or an "enhance[d] sense of competence, clarity of identity, and effectiveness" (p. 614).

\section{Mentoring Model}

Yob and Crawford (2012) designed a conceptual framework for mentoring in doctoral programs in higher education following an extensive review of mentoring literature. Two domains exist within this balanced framework: academic and psychosocial. Within the two domains, Yob and Crawford identified specific attributes. The academic domain "encompasses technical and informational functions of the mentor that support mentee development of appropriate knowledge, skills, and attitudes" and includes attributes of competence, availability, induction, and challenge (p. 41). The psychosocial domain "includes the qualities and skills in building and sustaining interpersonal relationships and the values, attitudes, and affects involved in mentoring" and entails personal qualities, communication, and emotional support attributes (p. 44). These mentoring characteristics and behaviors complement and align with several frameworks mentioned previously (i.e., Connolly et al., 2018; Curtin et al., 2016; Lent et al., 1994; Paglis et al., 2006).

Table 3: Summary of Conceptual Frameworks That Inform Mentoring Models

\begin{tabular}{lll}
\hline Conceptual Framework & Key Concepts & $\begin{array}{l}\text { Alignment to Mentoring } \\
\text { Pathways Program }\end{array}$ \\
\hline $\begin{array}{l}\text { Mentoring Phases Model (Kram, } \\
\text { 1983) }\end{array}$ & $\begin{array}{l}\text { Evolving relationships focused } \\
\text { on psychosocial and career- } \\
\text { oriented growth. }\end{array}$ & $\begin{array}{l}\text { EdD students experience } \\
\text { opportunities to explore several } \\
\text { career and social pathways in }\end{array}$ \\
& MPP. \\
$\begin{array}{l}\text { Mentoring Model (Yob \& } \\
\text { Crawford, 2012) }\end{array}$ & $\begin{array}{l}\text { EdD students experience } \\
\text { focus for mentoring. }\end{array}$ & $\begin{array}{l}\text { discussions and presentations } \\
\text { focused on several academic and } \\
\text { psychosocial domains in MPP. }\end{array}$ \\
& & \\
\hline
\end{tabular}

Note: MPP = Mentoring Pathways Program.

\section{The Researchers' Doctor of Education Program}

Our Doctor of Education (EdD) program is a part of the Department of Educational Leadership at a mid-sized, Midwestern institution. Typically, EdD students are scholar-practitioners who work full time in educationrelated positions (e.g., teacher, principal, curriculum director, superintendent) and pursue their doctorate with the goal of completing the degree within three to five years. The students enter the program in a cohort, and the courses are taken in a hybrid format as students attend class together, in-person, once a month and complete the rest of the coursework online for the first two to three years of the program. Upon the completion of coursework and the comprehensive exam, EdD students work directly with their dissertation chair and program advisor to complete their dissertation and degree program.

\section{Mentoring Pathways Program Development}

The educational program for $\mathrm{EdD}$ students varies from that of traditional $\mathrm{PhD}$ programs given the nature of the EdD and the focus on scholar-practitioners. Since EdD students typically work full time in educational leadership positions while taking courses and writing a dissertation, a mentoring program for EdD students was developed to support students and encourage degree completion. In the following subsections, we discuss 
considerations used to develop the Mentoring Pathways Program model and descriptions of the program framework's design and shifts each year.

\section{Program Creation Considerations}

The Mentoring Pathways Program was designed to complement the EdD program by considering the needs of each cohort based on where they are in the degree program. The needs of students in the first year of the program differ from those of students in the later stages of the program. The initial conceptualization of the program was to support EdD students' acclimation to the EdD program and having questions answered by graduates of the program or by students further along in the program, with the ultimate goal of increasing retention of EdD students. Gaskill's (1993) mentoring framework emphasizes that giving mentees a thirdparty sounding board allows them a nonjudgmental arena where they can discuss their struggles and seek advice, and thus we sought to give our students an additional support alongside their faculty advisors and instructors. Through research and reflection, our mentoring approach has undergone several changes in an effort to best meet the needs of our students, aligning with Burlew's (1991) idea that "mentoring is not a single event... but rather several events with different levels of mentoring” (p. 220).

\section{Year 1: Peer Mentoring (One-to-One)}

In 2016, two faculty members and one graduate assistant in the educational leadership department designed a mentoring program for EdD students based on students' expressed interest in a program for social, emotional, academic, and career support from fellow EdD students and graduates. Additionally, faculty desired to provide students with another type of support system to supplement guidance students receive from their professors, program advisor, dissertation chair, and dissertation committee members. We referred to Yob and Crawford's (2012) conceptual framework for the design and purpose of the mentoring program for EdD students, as this framework sets out the mentoring relationship as not only providing academic and career support but additionally psychosocial support.

A peer mentoring program was established for first-year EdD students who were paired with graduates of the program or students who were further along in our EdD program to serve as mentors (Burlew, 1991; Geesa et al., 2018; Li, 2018; Lowery et al., 2019; McConnell et al., 2019). These mentors were recruited based upon recommendations from faculty and attended a training session to orient them to the purpose and goal of their mentoring role (Gaskill, 1993). Mentors and mentees were paired together based upon common research interests, career paths, and geographic location. Through this one-to-one peer mentoring program, students were expected to meet with their mentor at least once a month via phone, web-conference, or in-person with an additional check-in once a month via text or e-mail.

As recommended by Gaskill's (1993) mentoring framework, an evaluation of the mentoring program was conducted at the end of the first academic year in order to measure both benefits and areas for growth. This evaluation took the form of both quantitative surveys and interviews and focus groups with mentors and mentees at the end of the 2016-2017 academic year (Geesa et al., 2018; Lowery et al., 2019; McConnell et al., 2019). Although mentees and mentors alike expressed generally positive experiences about the first year of the mentoring program, many participants felt a one-on-one form of mentoring was not necessary in the first year of the EdD program primarily because the mentees were completing coursework and did not feel they needed much support in that area (Geesa et al., 2018; Lowery et al., 2019; McConnell et al., 2019). This feedback, along with the difficulties of finding enough mentors to match with mentees each year, led to a redesign of the mentoring program for the second year. 


\section{Year 2: Group Mentoring (Presentations and Facilitator Discussion)}

While continuing to refer to Yob and Crawford's (2012) conceptual framework, the mentoring program was reconceptualized as a group format during the 2017-2018 academic year for first- and second-year students in an effort to better meet the needs of education doctoral students who were taking coursework but not yet writing their dissertation. This shift from a peer, one-to-one mentoring format to a group mentoring format allowed us to facilitate monthly face-to-face meetings with groups of first- and second-year students who voluntarily chose to participate in one-hour meetings with mentors prior to their in-person EdD course meetings. During the group mentoring meetings, we served as facilitators while one or two mentors provided a 25-30 minute presentation in-person or via web-conference to the mentees (Geesa et al., 2020; McConnell et al., 2020). The presentation themes included comprehensive exams, dissertation topics, and work-life balance. This format required less time and commitment from mentors, and allowed mentees to learn from several different mentors, as well as giving them a forum to interact with and support one another.

Following the presentations, students could ask the mentor(s) questions and received the contact information of the mentors, should they choose to reach out for additional support. Upon review of mentor and mentee feedback and reflections of the group mentoring program, we recognized that mentees found this format to be more meaningful to them than the one-to-one peer mentoring design. However, mentees and mentors desired more interaction with one another during the meetings. This redesign primarily represented a shift in the Dawson (2014) mentoring program design elements of cardinality, by moving from one-to-one mentoring to one-to-many mentoring, and activities, by shifting from a loose general focus to a scheduled monthly presentation and discussion. Following the completion of the 2017-2018 academic year, feedback was again sought through surveys and focus groups, resulting in a focus shift for the following academic year (Gaskill, 1993; Geesa et al., 2020; McConnell et al., 2019).

\section{Year 3: Group Mentoring (Presentations and Roundtable Discussions)}

Reconceptualizing the mentoring program for the 2018-2019 academic school year for first- and second-year students expanded the theoretical foundations for our approach. With Yob and Crawford's (2012) conceptual framework in place, we identified Social Cognitive Career Theory (Lent et al., 1994) as a way to theoretically frame aspects of mentoring not previously considered in the program, such as self-efficacy and self-regulation. While maintaining the essence of the group mentoring format, we made slight changes between the Year 2 and Year 3 mentoring programs to allow us to engage more with mentees and mentors regarding the topics and discussion questions.

Prior to the beginning of the school year, mentees completed surveys regarding presentation topics and their desire to have discussions with mentors, facilitators, and fellow mentees in the meetings. The feedback and insights we received from mentees about presentation and discussion topics allowed us to redesign the program to better meet the mentees' needs. During the one-hour monthly face-to-face meetings, first- and second-year students participated in the group mentoring sessions by meeting with their peers, facilitators, and mentors who shared a short 10-15 minute presentation based on the list of requested topics and guided a roundtable discussion to address questions students posed in-person or via web-conference.

Group mentoring and peer mentoring were offered to first-and second-year EdD students, relating to Dawson's (2014) mentoring design element of relative seniority, which removes the idea of cardinality and accepted experience usually associated with mentors. This adjusted our view on how mentoring was being defined for the program (Burlew, 1991). Based on feedback from mentors and mentees at the end of the 20182019 school year, this form of group mentoring with presentations and roundtable discussions facilitated by a variety of graduates and faculty was beneficial for first- and second-year EdD students. Both mentors and mentees expressed that a shift to a one-to-one mentoring program may be more conducive to students who are in their third-year of the program as they transition from coursework to solely focusing on their 
dissertation research and writing plans to graduate. This feedback led to an expansion of the program in order to better meet the needs of first-, second-, and third-year students, in addition to other students who are working on their dissertations.

\section{Year 4: Multiple and Sequential Mentoring (Presentation and Roundtable Discussion and One-to-One)}

Due to potential program changes and discussions related to faculty goals for the EdD program, we spent the Fall 2019 semester redesigning the mentoring program to provide additional supports to students throughout their entire doctoral experience. With feedback from doctoral students, mentors, and faculty, EdD faculty approved a Mentoring Pathways Program proposal, and the program began again in Spring 2020. We continued to use the conceptual framework for mentoring in doctoral programs by Yob and Crawford (2012) and social cognitive career theory by Lent et al. (2014) during the 2019-2020 program.

The mentoring program design included multiple forms of mentoring and was sequential in nature. First- and second-year EdD students experienced a group mentoring program or Community of Practice, in which a number of like-minded persons with a common interest or purpose meet to discuss significant issues that impact everyone. As with the design of the 2018-2019 mentoring program, students met before class once a month for a group mentoring session facilitated by a mentor or group of mentors with presentation and roundtable discussion, but students had the discussion topics in advance and were expected to come to the session with questions and their own discussion points related to the topics. Outside of the formal mentoring presentations and roundtable discussions, cohorts of mentees found additional mentoring and community through discussion of mentoring topics amongst themselves and reaching out to mentors for additional questions or advice. Topics of discussion included: coursework, work-life balance, writing time, dissertation topics, academic progress, research interests, future aspirations, and long-term and short-term goal planning

Doctoral students who are in their third year of the program or beyond typically are completing or have finished coursework and are working on their dissertation. This is an ideal time for EdD students to begin working with a mentor in a one-to-one format. Twenty-four students at this stage in the doctoral program participated in a survey about the mentoring program in 2019. In regard to the design of a mentoring program, ten out of $24 \mathrm{EdD}$ students wanted to work with someone who could serve as a coach while they worked on the dissertation. Five students expressed interest in working with someone at their same professional level and who could define issues and problems. Five students preferred to work with someone at a professional level to which they aspire.

Based on this feedback, we decided to begin a one-to-one mentoring program pilot for students who have completed their first two years of coursework and are working on their dissertation. As a voluntary program, EdD students who expressed a desire for a mentor were paired with mentors based on information provided in the survey in addition to commonalities in research topics, research methods, career aspirations, locations, and current professions. We expected mentees and mentors to meet or talk at least once per month while having additional communication via e-mail/text until the mentee completes the dissertation.

Communication and the topics discussed each month are documented. Similar to the past three years, we will collect data about the effectiveness of the program in order to determine the design of the program for all students in school year 2020-2021. Table 4 describes more information about the Mentoring Pathways Program approaches and frameworks used over the past four years. 
Table 4: Progression of the Mentoring Pathways Program

\begin{tabular}{|c|c|c|}
\hline Year & Mentoring Pathways Program Approach & Influencing Frameworks \\
\hline $\begin{array}{l}1 \\
2016-17\end{array}$ & $\begin{array}{l}\text { One-to-one mentor approach with first year EdD } \\
\text { students; faculty-, mentor-, and mentee-selected } \\
\text { topics discussed }\end{array}$ & Mentoring Model (Yob \& Crawford, 2012) \\
\hline $\begin{array}{l}2 \\
2017-18\end{array}$ & $\begin{array}{l}\text { Group-mentoring approach with first- and } \\
\text { second-year EdD students; faculty- and mentor- } \\
\text { selected topics discussed }\end{array}$ & Mentoring Model (Yob \& Crawford, 2012) \\
\hline $\begin{array}{l}3 \\
2018-19\end{array}$ & $\begin{array}{l}\text { Group-mentoring and peer-mentoring approach } \\
\text { with first- and second-year EdD students; } \\
\text { mentee-selected topics discussed }\end{array}$ & $\begin{array}{l}\text { Mentoring Model (Yob \& Crawford, 2012) \& } \\
\text { Social Cognitive Career Theory (Lent et al., } \\
\text { 1994) }\end{array}$ \\
\hline \multirow[t]{2}{*}{$\begin{array}{l}4 \\
2019-20\end{array}$} & $\begin{array}{l}\text { Group-mentoring and peer-mentoring approach } \\
\text { with first- and second-year EdD students; } \\
\text { student selected topics discussed }\end{array}$ & $\begin{array}{l}\text { Mentoring Model (Yob \& Crawford) \& Social } \\
\text { Cognitive Career Theory (Lent et al., 1994) }\end{array}$ \\
\hline & $\begin{array}{l}\text { One-to-one mentoring approach with third- year } \\
\text { students and other students completing their } \\
\text { dissertation; mentee- and mentor- selected } \\
\text { topics discussed }\end{array}$ & \\
\hline
\end{tabular}

\section{Conceptual Framework Model for the Mentoring Pathways Program}

The need to develop a conceptual framework for the Mentoring Pathways Program for EdD students became evident following the second redesign of our mentoring program in the 2017-2018 school year, in which we realized the need to conceptualize our process in order to understand the intended impact and continued growth of the program (Burlew, 1991; Campbell et al., 2012; Crisp \& Cruz, 2009; Gaskill, 1993; Li, 2018; Kumar \& Antonenko, 2014; West, 2016). While the purpose for each redesign was responsive to both mentor and mentee needs, previous program designs had centered around a single framework that did not encompass the program's purpose in its entirety (Li, 2018; Yob \& Crawford, 2012). The addition of SCCT (Lent et al., 1994) in the second redesign increased our interest and need to further research mentoring frameworks and the potential connection to our own program to ensure effectiveness and productivity. We considered key concepts from both theoretical and conceptual frameworks in the development of our Mentoring Pathways Program model (see Table 2 and Table 3).

Developing a conceptual framework specific to a hybrid doctoral program in educational leadership that blends traditional face-to-face teaching with web-based online learning allowed us to solidify our foundational beliefs and align with theory and research in the field (Burlew, 1991). Leaning towards a "reform-minded approach" in which the program focuses on transitioning into the doctoral program and developing "healthy professional identit[ies] and positive" self-efficacy (West, 2016, p. 26), the Mentoring Pathways Program also employs varied aspects of learning, as discussed earlier in the article.

In developing the Mentoring Pathways Program framework (see Figure 1), we focused on two domainssustainability and networking-supported by three personal attributes: readiness, self-efficacy, and progress. These components all lead to expected outcomes. Sustainability and networking are necessary to achieve expected outcomes. Networking is often made possible through sustained relationships, which tend to be maintained by the continued production of expected outcomes (i.e. new positions, doctoral completion, etc.). Likewise, sustainability is maintained through the continued growth of networking possibilities derived from continued success of the program candidates. In turn, the expected outcomes, whether academic, career, or 
psychosocially oriented, are supported by the ability to network in a sustained environment. The domains, along with expected outcomes, also interact with the personal attributes in addition to being a product of them. Ultimately, however, the goal of the Mentoring Pathways Program is to achieve expected outcomes, specific to both the doctoral program and each individual's personal goals. An explanation of each domain and how the personal attributes influence expected outcomes follows.

Figure 1: Mentoring Pathways Program Model

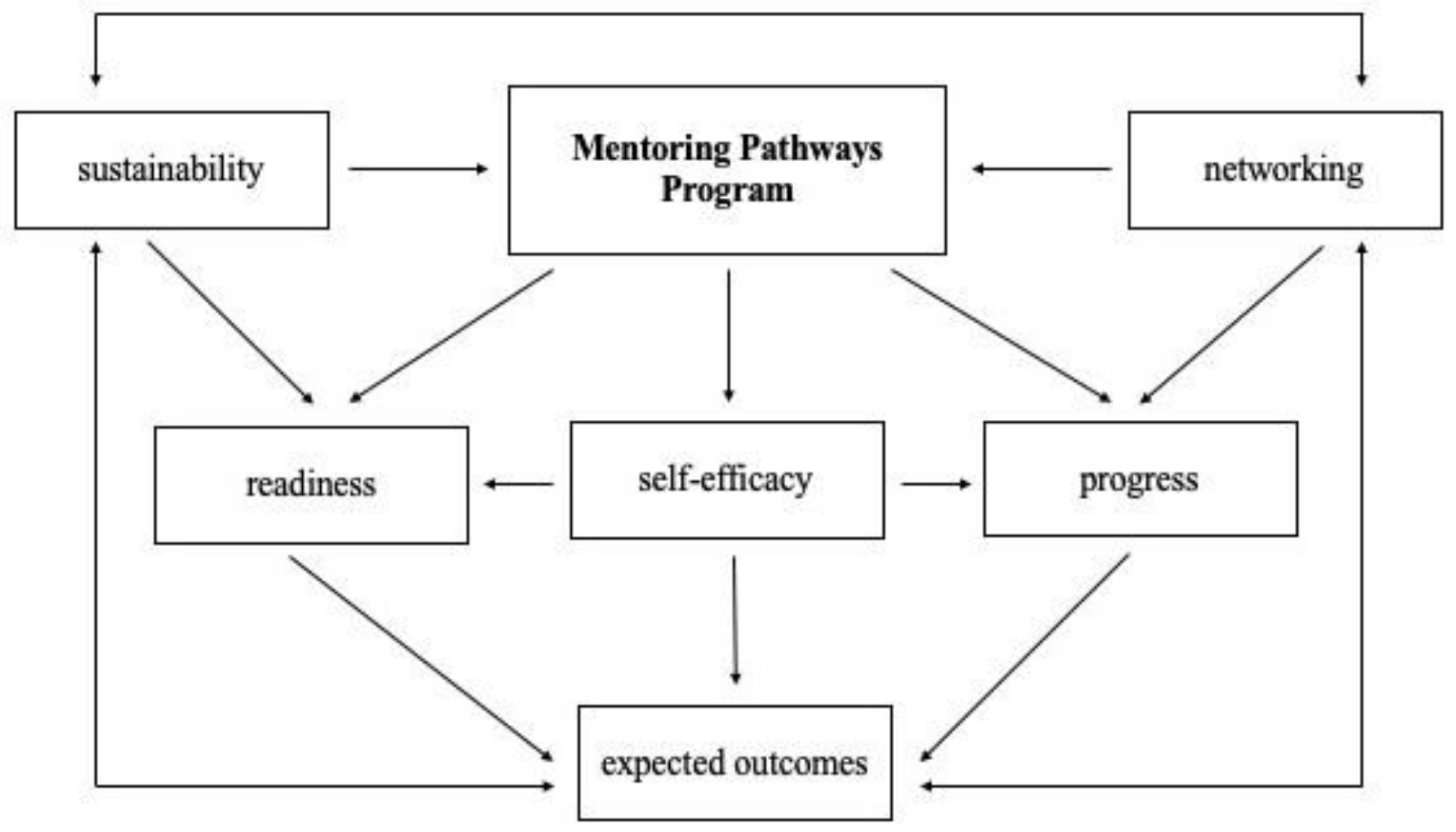

\section{Personal Attributes}

\section{Readiness}

Doctoral students enter their programs with wide-ranging amounts of readiness. As such, mentoring programs must be designed not only to address these varying levels by differentiating for them but also in selecting mentors who also display a readiness to expand and enhance their own learning (Klinge, 2015; Lowery et al., 2018; McConnell et al., 2019). Through the use of surveys, readiness can be pre-assessed to determine both individual and group readiness for specific cohorts at the beginning of each year (Geesa et al., 2020; Larose, 2013). As shown in Figure 1, self-efficacy and sustainability encourage readiness by providing consistent mentoring focused on increasing knowledge and awareness for the mentee.

\section{Self-Efficacy}

To meet an expected outcome, individuals must employ specific behaviors which are influenced by their beliefs regarding achievement (Bandura, 1977). These individual beliefs, however, can be influenced by outside forces (e.g., a mentor, educational experiences, etc.) (Curtin et al., 2014; Lent \& Brown, 2013). Selfefficacy is the central focus of the Mentoring Pathways Program Model (see Figure 1), as it influences readiness, progress, and expected outcomes. Doctoral students must be armed with the ability to accept and move forward when setbacks occur. Providing both group and peer mentoring opportunities supports this effort through connecting individuals with similar experiences. "How students perceive the characteristics of their social environment... influence[s] these courses of action beyond dispositions” (Stajkovic et al., 2018). 


\section{Progress}

Individual progression through a doctoral program varies, but the expected outcome for each EdD student is the same: degree completion (Geesa et al., 2020; Geesa et al., 2018; Lowery et al., 2018). Progress is monitored by completion of coursework, personal goal achievement, and evolution of the dissertation itself. Particularly helpful within this discipline is the approach to mentoring, which should be specific to the needs of the mentee based on progression in the program. For example, group mentoring and peer mentoring are particularly helpful during the early years of the EdD program in which individuals are primarily engaged in coursework. In the later years of the program, however, individuals may benefit more from a one-to-one mentoring approach in which interactions can be differentiated appropriately for the participating mentee (Crisp \& Cruz, 2009; Dawson, 2014; Geesa et al., 2020; Geesa et al., 2018; Li, 2018; Lowery et al., 2019; Lowery et al., 2018; Wang \& Odell, 2007).

\section{Domains}

\section{Sustainability}

The ability to sustain a mentoring program is paramount to the success of its participants and the program itself. A substantial amount of time is often devoted to creating and implementing mentoring programs, likely resulting in adjustments or complete redesigns (Geesa et al., 2020). Within this context, sustainability is both supported by and supports other components of the Mentoring Pathways Program.

\section{Networking}

Professional progress is often about who we know. Our EdD program attracts a diverse group of scholarpractitioners with a shared purpose, who otherwise may never cross paths. This alone provides an environment for networking among peers in collaboration with faculty who teach the courses. Additionally, employing the use of EdD alumni provides another avenue of networking, broadening the exposure of possibilities. Progress in the program increases networking potentiality, as some mentors only participate in particular approaches of mentoring (group or one-to-one).

\section{Expected Outcomes}

On the surface, most expected outcomes focus on timelines and completion rates. However, when working with scholar-practitioners other dynamics can factor into this category. Doctoral students are often looking towards career advancement or considering alternate career pathways. The Mentoring Pathways Program connects readiness, self-efficacy, progress, sustainability, and networking for the purpose of achieving both individual and program goals (see Figure 1).

\section{Discussion}

The development of a conceptual framework model for the Mentoring Pathways Program focused on establishing a mentoring definition and identifying the theoretical and conceptual frameworks that guided the design of the program (Burlew, 1991). As previously mentioned, mentoring is not focused on a hierarchical approach but rather on the support participants can provide each other while working towards desired outcomes (see Figure 1). Each participant could potentially fluctuate between the roles of mentor and mentee depending on individual levels of readiness, self-efficacy, and progress, as well as what can be offered through networking. The frameworks informing our mentoring program design provide guidance for addressing both academic and psychosocial supports while also advocating for participant input (see Table 3 and Table 4). The main frameworks we used were Yob and Crawford's mentoring model (2012) and SCCT (Lent et al., 1994), and both approaches were heavily influenced by previous research in the field (see Table 1).

Continual evaluation and redesign of mentoring programs is imperative in order to ensure that programs are consistently meeting the goals and needs of the participants (Gaskill, 1993). This evaluation and redesign 
process may be challenging for faculty as they manage other roles and responsibilities. Noonan and colleagues (2007) recommend that mentoring programs and mentors directly ask mentees what their needs are and what forms of assistance they require to meet those needs. Kram (1985) encourages constant monitoring of programs not only to gather information on how to implement change, but to also build buy-in with stakeholders of the mentoring program. The productive mentoring framework, as proposed by Simmie and Moles (2011), also encourages a learner-centric model of mentoring in which mentees are considered an important voice in deciding upon the structure and content of mentoring programs.

In order to continually improve the Mentoring Pathways Program, participants in the program were surveyed, interviewed, and asked to participate in focus groups after each academic year. The feedback and data gathered from these evaluation methods led to changes or updates in the form, method, and content of the Mentoring Pathways Program to best suit our ever-changing group of mentees. Future researchers should consult with doctoral program faculty, graduates, and current students in their institution to understand their unique needs and to design a program that best supports them. Starting from a base dyadic model of mentoring in Year 1, we soon learned that a group mentoring model would better meet the needs of our mentees. While this group presentation model fulfilled the academic domain of Yob and Crawford's (2012) mentoring conceptual framework, evaluation of the Year 2 mentoring participants during the 2017-2018 school year revealed that both mentors and mentees felt that they were missing another vital ingredient of mentoring: the psychosocial domain. Mentees indicated they would like to continue with group mentoring, but an added component of peer mentoring would be beneficial for the mentees who are taking courses and have not started their dissertation processes, aligning with the adaptability component of SCCT while also demonstrating a self-regulatory approach to learning (Lent et al., 1994).

Appropriate changes were made once again to modify the Mentoring Pathways Program for Year 3. In this iteration, mentees received information to help fulfill the academic domain of the mentoring model, but both mentees and mentors also received psychosocial support in the form of group connectivity and interpersonal connection (Yob \& Crawford, 2012). Additionally, mentees were able to enact a more intentional approach for their own learning by targeting specific interests, skills, and knowledge sought by the mentees in relation to their own development and progress through the mentoring program (Carpenter et al., 2015; Connolly et al., 2018; Curtin et al., 2016). Researchers should be prepared to adjust the design of the program each year as they gain more information about the assets and deficits of the current program. In Year 4, the Mentoring Pathways Program was expanded to include students who completed their first two years of the doctoral program and were working on their dissertations in a one-to-one peer mentoring format.

\section{Limitations}

University mentoring programs at the doctoral level range in purpose, structure, and length, as doctoral mentoring programs are often dependent upon individual program needs and outcome expectations (Burlew, 1991; Carpenter et al., 2015; Crisp \& Cruz, 2009; Dawson, 2014; University of Melbourne, 2012). Due to the unique needs of EdD students, who are typically scholar-practitioners and hold educational leadership roles in schools, districts, and organizations, the design of an EdD mentoring program may differ from mentoring programs for traditional $\mathrm{PhD}$ students who may be on campus and working as graduate assistants during their time as doctoral students. The Mentoring Pathways Program was designed by researchers from one institution, and the program took place in that institution. The fact that no research was conducted outside of this institution is a limitation of the study. Additionally, the EdD program in our institution is a hybrid program where students only meet once each month while completing other coursework requirements asynchronously online. Determining which frameworks best align with the expectations and requirements of a specified EdD program requires a thorough investigation of both theoretical and practical application. As 
such, this will be a continuous process of reflection and adaptation as we work to maintain an effective mentoring approach.

\section{Next Steps}

The Mentoring Pathways Program model has been empirically tested in our institution; however more testing is needed in other institutions with differing doctoral programs. Each institution will need to provide a mentoring program that is unique to their doctoral program's and students' needs. One aspect of mentoring not widely explored, and not explored at all within the Mentoring Pathways Program, is distinguishing between different "mentors" in a student's life, including, but not limited to: faculty advisor, dissertation chair, committee member, peer mentor, cohort member/classmate, and outside support (family, friends, colleagues, others outside of the academic program). Although each of these roles offers different supports to a student, in theory, the lines between roles often get blurred, or may seem indistinguishable. Our next steps in the Mentoring Pathways Program include exploring the differences between these support systems and investigating how the many mentorship figures in a student's life contribute, individually or in tandem, to the successful completion of the degree path.

\section{Conclusion}

The Mentoring Pathways Program model provides an example of how university programs can design effective mentoring programs for their students; however, its application is not limited to doctoral students. The theoretical foundations and conceptual frameworks which informed this model are relevant to a variety of professional fields of study. The desire to create sustainable systems that promote networking and assist individuals in meeting expected outcomes result in several ideas and applications (Campbell et al., 2012; Connolly et al., 2018; Curtin et al., 2016; Lent et al., 1994; Paglis et al., 2006; Yob \& Crawford, 2012). For our program, participating in the Mentoring Pathways sessions and receiving feedback from participants solidified the idea that mentoring programs must be adaptable to consistently address the needs of students. Those needs change with each semester as students' coursework, work obligations, and personal lives shift to accommodate progression through the program and their professional goals. The development of the Mentoring Pathways Program Model ensures a focused and continued approach to the program based on the underlying theoretical and conceptual frameworks which capture our intent. This model will continue to be influenced by feedback provided by all stakeholders each year to better meet the needs of EdD students at various phases of their doctoral degree progression. 


\section{References}

Baker, V. (2015). People strategy in human resources: Lessons for mentoring in higher education. Mentoring \& Tutoring: Partnership in Learning, 23(1), 6-18. https://doi.org/10.1080/13611267.2015.1011034

Bandura, A. (1977). Self-efficacy: Toward a unifying theory of behavior change. Psychological Review, 84(2), 191-215.

Bandura, A. (1986). Social foundations of thought and action: A social cognitivetheory. Prentice Hall.

Bandura, A. (1997). Self-efficacy: The exercise of control. W. H. Freeman andCompany.

Bandura, A. (2019). Applying theory for human betterment. Perspectives on Psychological Science, 14(1), 1215. https://doi.org/10.1177/1745691618815165.

Burlew, L. (1991). Multiple mentor model: A conceptual framework. Journal of Career Development, 17(3), 213-221. https://doi.org/10.1007/BFo1322028

Burney, V. H. (2008). Applications of social cognitive theory to gifted education. Roeper Review, 30(2), 130139. https://doi.org/10.1080/02783190801955335

Campbell, C. M., Smith, M., Dugan, J. P., \& Komives, S. R. (2012). Mentors and college student leadership outcomes: The importance of position and process. The Review of Higher Education, 35(4), 595-625. https://doi.org/10.1353/rhe.2012.0037

Carpenter, S., Makhadmeh, N., \& Thornton, L. J. (2015). Mentorship on the doctoral level: An examination of communication faculty mentors' traits and functions. Communication Education, 64(3), 366-386. https://doi.org/10.1080/03634523.2015.1041997

Chun, J. U., Sosik, J. J., \& Yun, N. Y. (2012). A longitudinal study of mentor and protégé outcomes in formal mentoring relationships. Journal of Organizational Behavior, 33(8), 1071-1094. https://doi.org/10.1002/job.1781

Connolly, M. R., Lee, Y.-G., \& Savoy, J. N. (2018). The effects of doctoral teaching development on earlycareer STEM scholar's college teaching self-efficacy. CBE Life Science Education, 17(1), 1-15. https://doi.org/10.1187/cbe.17-02-0039

Crisp, G. \& Cruz, I. (2009). Mentoring college students: A critical review of the literature between 1990 and 2007. Research in Higher Education, 5o(6), 525-545. https://doi.org/10.1007/s11162-009-9130-2

Curtin, N., Malley, J., \& Steward, A. J. (2016). Mentoring the next generation of faculty: Supporting academic career aspirations among doctoral students. Research in Higher Education, 57(6), 714-738. https://doi.org/10.1007/s11162-015-9403-x

Dawson, P. (2014). Beyond a definition: Toward a framework for designing and specifying mentoring models. Educational Research, 43(3), 137-145. https://doi.org/10.3102/0013189X14528751

Dominguez, N. \& Hager, M. (2013). Mentoring frameworks: Synthesis and critique. International Journal of Mentoring and Coaching in Education, 2(3), 171-188. https://doi.org/10.1108/ijmce-03-2013-0014

Eby, L. T., Rhodes, J. E., \& Allen, T. D. (2010). Definition and evolution of mentoring. In T. D. Allen \& L. T. Eby (Eds.), The Blackwell handbook of mentoring: A multiple perspectives approach (7-20). John Wiley \& Sons. https://doi.org/10.1111/b.9781405133739.2007.00002.X

Gaskill, L. R. (1993). A conceptual framework for the development, implementation, and evaluation of formal mentoring programs. Journal for Career Development, 20(2), 147-160. https://doi.org/10.1177/089484539302000205 
Geesa, R. L., Brown, R., \& McConnell, K. (2020). Mentoring pathways program for first year doctor of education students: Perspectives of a program redesigned for sustainability. Mentoring \& Tutoring: Partnership in Learning, 28(2), 156-175. https://doi.org/10.1080/13611267.2020.1749346

Geesa, R. L., Lowery, K., \& McConnell, K. (2018). Mentee perspectives of a first year peer mentoring program for educational doctoral (EdD) students. International Journal of Doctoral Studies, 13, 471-495. https://doi.org/10.28945/4148

Hargreaves, A., \& Fullan, M. (2000). Mentoring in the new millennium. Theory into Practice, 39(1), 50-56. https://doi.org/10.1207/s15430421tip3901 8

Jacobi, M. (1991). Mentoring and undergraduate academic success: A literature review. Review of Educational Research, 61(4), 505-532. https://doi.org/10.3102/00346543061004505

Klinge, C. M. (2015). A conceptual framework for mentoring in a learning organization. Adult Learning, 26(4), 159-166. https://doi.org/10.1177/1045159515594154

Kram, K. E. (1983). Phases of the mentor relationship. Academy of Management Journal, 26(4), 608-625. https://doi.org/10.5465/255910

Kram, K. E. (1985). Improving the mentoring process. Training and Development Journal, 39(4), 40-43.

Kumar, S. \& Antonenko, P. (2014). Connecting practice, theory, and method: Supporting professional doctoral students in developing conceptual frameworks. TechTrends, 58(4), 54-61. https://doi.org/10.1007/s11528-014-0769-y

Larose, S. (2013). Trajectories of mentor's perceived self-efficacy during an academic mentoring experience: What they look like and what are their personal and experimental correlates? Mentoring and Tutoring, 21(4), 150-174. https://doi.org/10.1080/13611267.2013.813728

Lent, R. W. \& Brown, S. D. (2013). Social cognitive model of career self-management: Toward a unifying view of adaptive career behavior across the life span. Journal of Counseling Psychology, 6o(4), 557-568. https://doi.org/10.1037/a0033446

Lent, R. W., Brown, S. D., \& Hackett, G. (1994). Toward a unifying social cognitive theory of career and academic interest, choice, and performance. Journal of Vocational Behavior, 45(1), 79-122. https://doi.org/10.1006/jvbe.1994.1027

Levinson, D. J. (2009). The Season of a Man's Life. Penguin Random House.

Li, S., Malin, J. R., \& Hackman, D. G. (2018). Mentoring supports and mentoring across difference: Insights from mentees. Mentoring \& Tutoring: Partnership in Learning, 26(5), 563-584. https://doi.org/10.10880/13611267.2018.1561020

Lowery, K., Geesa, R., \& McConnell, K. (2018). A review of peer mentoring in graduate school literature for the design of a peer mentoring program for education doctorate (EdD) students. Higher Learning Research Communications, 8(1), 1-21. http://dx.doi.org/10.18870/hlrc.v8i1.408

Lowery, K., Geesa, R. L., \& McConnell, K. (2019). Self-regulated learning of mentees and mentors in an education doctorate peer mentoring program. Mid-Western Educational Researcher, 31(2), 186-209. https://www.mwera.org/MWER/

Martin, A. J. \& Dowson, M. (2009). Interpersonal relationships, motivation, engagement, and achievement: Yields for theory, current issues, and educational practice. Review of Educational Research, 79(1), 327-365. https://dx.doi.org/10.3102/0034654308325583

Maynard, T., \& Furlong, J. (1995). Learning to teach and models of mentoring. In T. Kerry \& A. S. Mayes (Eds.), Issues in mentoring (pp. 10-24). Routledge. 
McConnell, K., Geesa, R., \& Brown, R. (2020) Mentor perceptions of the purpose and focus of a doctoral mentoring program. [Manuscript submitted for publication]. Ball State University.

McConnell, K., Geesa, R. L., \& Lowery, K. (2019). Self-reflective mentoring: Perspectives of peer mentors in an education doctoral program. International Journal of Mentoring and Coaching in Education, 8(2), 86-101. https://doi.org/10.1108/IJMCE-07-2018-0043

Meyer, K. C., \& Bouchey, H.A. (2010). Daring to DREAM: Results from a mentoring programme for at-risk youth. International Journal of Evidence Based Coaching and Mentoring, 8(1), 67-84. https://researchportal.coachfederation.org/Document/Pdf/abstract 1954

Noonan, M. J., Ballinger, R., \& Black, R. (2007). Peer and faculty mentoring in doctoral education: Definitions, experiences, and expectations. International Journal of Teaching and Learning in Higher Education, 19(3), 251-262. https://files.eric.ed.gov/fulltext/EJ901298.pdf

Paglis, L. L., Green, S. G., \& Bauer, T. N. (2006). Does advisor mentoring add value? A longitudinal survey of mentoring and doctoral student outcomes. Research in Higher Education, 47(4), 451-476. https://doi.org/10.1007/s11162-005-9003-2

Simmie, G. M. \& Moles, J. (2011). Critical thinking, caring and professional agency: An emerging framework in productive mentoring. Mentoring and Tutoring: Partnership in Learning, 19(4), 465-482. https://doi.org/10.1080/13611267.2011.622081

Stajkovic, A. D., Bandura, A., Locke, E. A., Lee, D., \& Sergent, K. (2018). Test of three conceptual models of influence of the big five personality traits and self-efficacy on academic performance: A meta-analytic path-analysis. Personality and Individual Differences, 12O, 238-245. https://doi.org/10.1016/j.paid.2017.08.014

Tonidandel, S., Avery, D. R., \& Phillips, M. G. (2007). Maximizing returns on mentoring: Factors affecting subsequent protégé performance. Journal of Organizational Behavior, 28(1), 89-110. https://doi.org/10.1002/job.418

University of Melbourne. (2012). What types of mentoring relationships exist? Author. http://ranch.net.au/wp-content/uploads/2018/o9/Mentoring-Types.pdf

Varghese, L., \& Finkelstein, L. (2020). An investigation of self-efficacy crossover between mentors and proteges within mentoring dyads: Mentoring and self-efficacy. Annals of the New York Academy of Sciences, 1-19. https://doi.org/10.1111/nyas.14324.

Wang, J., \& Odell, S. J. (2007). An alternative conception of mentor-novice relationships: Learning to teach in reform-minded ways as a context. Teaching and Teacher Education: An International Journal of Research and Studies, 23(4), 473-489. https://doi.org/10.1016/j.tate.2006.12.010

West, A. (2016). A framework for conceptualizing models of mentoring in educational settings. International Journal of Leadership and Change, 4(1), 23-29. https://digitalcommons.wku.edu/ijlc/vol4/iss1/11

Yob, I. \& Crawford, L. (2012). Conceptual framework for mentoring doctoral students. Higher Learning Research Communications, 2(2), 34-47. https://doi.org/10.18870/hlrc.v2i2.66

The Higher Learning Research Communications (HLRC), is a peer-reviewed, online, interdisciplinary journal indexed in Scopus, ERIC, JGATE and Directory of Open Access Journals (DOAJ). It is an open access journal with an international focus published by Walden University, USA. Its aim is to disseminate both high quality research and teaching best practices in tertiary education across cultures and disciplines. HLRC connects the ways research and best practice contribute to the public good and impact the communities that educators serve. $H L R C$ articles include peer-reviewed research reports, research briefs, comprehensive literature reviews, and books reviews. 